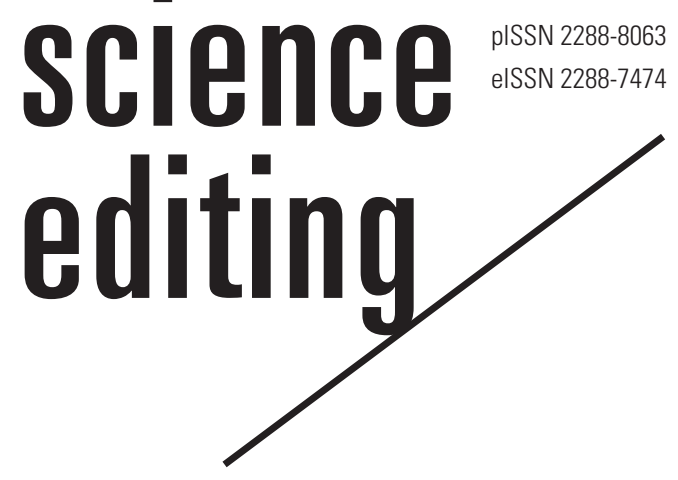

\title{
Engagement and integrity as the core of communication with examples from Samsung Electronics
}

\section{Essay}

\author{
In Yong Rhee \\ President, Corporate Relations, Samsung Electronics Co., Ltd., Seoul, Korea
}

\section{Introduction}

In this article, I would like to discuss the core of communication. I believe that I was invited to discuss this topic because I worked in communication and risk management at Samsung Electronics Co., Ltd. from 2005 to 2017. Prior to that, I worked as a TV reporter for the MBC Broadcasting Company from 1982 to 2005 after my graduation from Seoul National University with a major in Asian history. Therefore, my main job can be described as a "communicator." Although I worked in communications for 37 years, I still find it to be a difficult topic. I believe that I have found the reasons why communication is difficult. These days, we frequently talk about the importance of communication in all relationships: in politics, in a company like Samsung Electronics, at home, and among friends. Why do we frequently talk about communication? Because it makes us human.

\section{What is a Human Being?}

The Chinese word for human being is rénjiān [人間], which is composed of "man" (人) and "relationship" (間), suggesting that human beings are inherently grounded in relationships between people. Along similar lines, the Bible describes the first human being as follows: "God

Received: January 13, 2020

Accepted: January 15, 2020

Correspondence to In Yong Rhee iy.rhee@samsung.com

ORCID

In Yong Rhee

https://orcid.org/0000-0003-3415-1619

The content of this essay was presented at the Faculty Seminar of Hallym University, Korea, held on August 22, 2019 at Hotel Sol Beach, Samcheok, Korea. created the first human, Adam, and said: 'It is not good for man to be alone. I will make a helper suitable for him' (Genesis 2:18, New International Version)." This passage is often referred to as the beginning of the marriage system, but more fundamentally, it can be understood as evidence that human existence presupposes pluralism and relationships.

It is the essence of human life that paired people live together in a relationship, within which communication is a message transmitted between partners. One difficulty of communication arises because humans do not send and receive messages honestly, as we can frequently see in daily life. Furthermore, communication often does not go well even when we do try to send and receive information honestly. 


\section{science editing /}

\section{Examples of the Difficulty of Communication in Previous Literature}

\section{An excerpt from the Zhuangzi regarding the wheelwright P'ien}

Duke Huan was in his hall reading a book. The wheelwright P'ien, who was in the yard below chiseling a wheel, laid down his mallet and chisel, stepped up into the hall, and said to Duke Huan, "This book Your Grace is reading, may I venture to ask whose words are in it" "The words of the sages," said the duke. "Are the sages still alive?" "Dead long ago," said the duke. "In that case, what you are reading there is nothing but the chaff and dregs of the men of old!" "Since when does a wheelwright have permission to comment on the books I read?" said Duke Huan. "If you have some explanation, well and good. If not, it's your life!" Wheelwright P'ien said, "I look at it from the point of view of my own work. When I chisel a wheel, if the blows of the mallet are too gentle, the chisel slides and won't take hold. But if they're too hard, it bites in and won't budge. Not too gentle, not too hard, you can get it in your hand and feel it in your mind. You can't put it into words, and yet there's a knack to it somehow. I can't teach it to my son, and he can't learn it from me. So I've gone along for seventy years and at my age I'm still chiseling wheels. When the men of old died, they took with them the things that couldn't be handed down. So what you are reading there must be nothing but the chaff and dregs of the men of old" [1].

Confucius interpreted this phenomenon as follows: "The written characters are not the full exponent of speech, and speech is not the full expression of ideas; is it impossible then to discover the ideas of the sages?" [2]. This thought has been widely recognized since ancient times.

We believe that we see the things of the world as they are, but the experience of a single event can be described with quite different words. We believe that we see an event or an object as it is, objectively; however, in reality, we see it in our own way. A human sees in his or her own way, hears in his or her own way, and speaks in his or her own way.

Foreword of the History of the Peloponnesian War, written by the fifth-century BC historian Thucydides

"And with reference to the narrative of events, far from permitting myself to derive it from the first source that came to hand, I did not even trust my own impressions, but it rests partly on what I saw myself, partly on what others saw for me, the accuracy of the report being always tried by the most severe and detailed tests possible. My conclusions have cost me some labor from the want of coincidence between accounts of the same occurrences by different eye-witnesses, arising sometimes from imperfect memory, sometimes from undue partiality for one side or the other" [3].

To me, with my history major and journalistic background, the above quote from Thucydides is very impressive. The problem that historians lamented 2,500 years ago-the limits of human perception-is the same problem faced by journalists in the 21 st century.

\section{The Book of Genesis in the Bible}

Why has the failure to communicate appropriately plagued us since the first humans?

And the LORD God commanded the man, "You are free to eat from any tree in the garden; but you must not eat from the tree of the knowledge of good and evil, for when you eat from it you will certainly die" (Genesis 2: 16-17, New International Version).

The woman said to the serpent, "We may eat fruit from the trees in the garden, but God did say, 'you must not eat fruit from the tree that is in the middle of the garden, and you must not touch it, or you will die"' (Genesis 3:2-3, New International Version).

What is the meaning of the above two passages? Theologians call the first case an instance of distortion of communication. According to the Bible, after this instance of distorted communication, humans ate the fruit of the tree of the knowledge of good and evil, against God's instructions. If theologians are correct, the distortion of communication is the crime that caused the crime. Might one thus say that it is the number one crime?

\section{Core Values in Communication}

In the modern world, we frequently encounter distortions, limitations, biased judgment, and errors. I have thought sincerely about whether these may be essential aspects of human nature. Human existence is steeped in communication. In human relationships, we cannot persist without trust. Therefore, the core value in communication that enables human relationships is trust. The virtue for earning trust is honesty, a commitment that I will not view events in my own way, listen in my own way, or speak in my own way for my benefit. When talking with members of the communications team, I always said the following: "When any events happen to us, we should consider this: will our actions reflect well or poorly on the company?"

I believe that the social capital that is lacking in our society is trust. It is often said that Samsung is highly influential in our community, and that this influence is very burdensome. However, I believe that Samsung should serve as a good influence 
by increasing the social capital of trust through its communication activities. Of course, I have experienced numerous failures. In many cases, it was difficult to get past the company's internal decision-making process. I often felt helpless; nevertheless, I believe in learning through failures, addressing them, and moving forward. From this perspective, examples of the failure of honest communication may be precious.

\section{Three Examples of the Failure or Success of Communication with the Press and the Public at Samsung Electric}

In 2007, employees of a security services company that was a subsidiary of Samsung Group donned masks and illegally invaded the villas under their charge. The company initially said that those persons resigned about a week before the incident and were no longer its employees. However, the media later reported that the police had confirmed that the burglars were still employees of the security services company. The newspaper published that the subsidiary company's statements were false; therefore, the company had no choice but to admit to the lie. The public criticized the lies of Samsung's subsidiary company. Due to the deterioration of its public reputation, the company apologized for this event; furthermore, its CEO resigned. In this way, the criminal behavior of a few security officers sparked credibility and integrity issues for the entire company. This incident was more a matter of losing trust in the company than a matter of the security officers' criminal behavior.

The second incident was a hydrofluoric acid leak that occurred in January 2013 at a Samsung Electronics semiconductor factory. Unlike the previous case, this was an instance of unintentional communication failure. The first acid leak was reported at around 1 p.m. on Sunday, January 27, 2013. The hydrofluoric acid solution involved had a concentration of $50 \%$, such that it would not evaporate unless the temperature was over $100^{\circ} \mathrm{C}$. A worker at the factory was monitoring the leak; after 12 p.m., the magnitude of the leak increased, and the worker called an engineer to close the valve. The engineer decided to replace it. The valve replacement took place at 3:30 a.m.; after the replacement was completed, hydrofluoric acid vapor leaked out through tiny gaps in the valves. Then, an accident occurred. When the engineer went back to work, he neglected to wear proper work clothes and was transported to the hospital at around $8 \mathrm{a} . \mathrm{m}$. due to gas poisoning. Compounding the problem, Samsung executives were unaware of this. Eventually, the engineer died. This incident was reported to the police and was made known to the public. No Samsung employee was at the site, and one of the subcontractors who worked there and four wounded engineers went to the police after leaving the hospital. As the President of Communication of Samsung Electronics, I was not immediately aware of the incident at that time.

Therefore, I felt that my only option was to say that I would explain the facts as soon as the cause of the accident and the details of the situation were identified. However, because the accident had happened one-day prior, the mass media quickly raised suspicions of concealment. This situation was embarrassing to me, but it reminded me of the importance of understanding the fundamental facts when communicating with the press.

My third example is the blackout at the Samsung Electronics Giheung semiconductor factory. In August 2007, an online media outlet released a report entitled "Black smoke from Samsung Electronics semiconductor Giheung factory power outage, fire suspected." I was surprised to read this report because, while the description of an outage was correct, the part about the fire was not. At first, I told the press that the situation was a power outage, not a fire. A deputy general manager of the communications team told me, "All six lines of the K-2 semiconductor area have stopped functioning." It was a critical accident. If all six lines were disrupted, how significant must the disruption in semiconductor production have been? If six lines ceased to function at the company that supplies $30 \%$ of the world's memory semiconductors, the world's semiconductor market would devolve into chaos. The general manager asked me, "What shall I do?" The question was how to respond to media inquiries. At that moment, I experienced an inner conflict. I always talked to employees about trust and honesty, and I also couldn't hide or shrink from the press; it was evident that the impact would be too significant. Still, I hesitated to describe the accident precisely. When real situations arise, one can think of numerous excuses for why one should not follow the principles one has previously emphasized.

After some time, I told the general manager to report to the press that all six lines of the semiconductor factory were down due to a power outage. He was surprised and asked, "Can I?" I said, "You can cover it up for a few days, but it'll later become known that the six lines were down at the time of the accident. If that happens, it will be revealed that Samsung tried to conceal the size of the accident, and the company will lose credibility in the market. So even if it means that the impact is bigger right now, we have to tell the truth." I immediately went to the factory in Giheung and discussed the situation with the management team there. A factual report was dispatched to the communications team in Seoul and released to the media, who accepted Samsung's explanation. The next morning, the power outage was resolved, and the semiconductor factory plant regained normal function. The press an- 
nounced that Samsung had dealt with the situation with transparency, which increased the credibility of the company. Although it is somewhat painful and embarrassing to divulge personal examples such as these, they make it abundantly clear that the key is trust.

\section{Factors Determining Trust in a Company}

Edelman, a large American public relations firm and Samsung Group's global public relationship agency, publishes an annual report called the Trust Barometer. The 2013 edition included a description of the factors involved in determining the level of trust in a company by members of the public. Immediately after the financial crisis in 2008, operational excellence was the most influential factor in building corporate trust, but its importance has been decreasing for the past five years.

In order of importance, engagement is the first factor in determining the trust held in a company. Engagement is a relationship; specifically, it involves listening to customers' needs, treating employees well, prioritizing customers over profits, and communicating honestly and frequently about the business. The second is integrity: accurate and authentic behavior such as an ethical management style, responsible actions taken to correct issues or crises, and transparency and openness. The third is products and services for customers. Therefore, communication is the most essential key to the determination of public trust.

\section{Marketing and Non-market Strategies}

Companies look to the broader market with their marketing and non-market strategies. Market strategies refer to companies' systems for dealing with competitors, customers, and suppliers. In addition to the market environment mentioned above, the market in which the company operates is surrounded by non-market environments, such as politics, society, and culture. The non-market environment is invisible in the market, but it consists of laws, regulations, and social sentiments that influence the achievement of business goals. In modern times, companies must be competitive not only in market strategy but also in non-market strategy. The communications team of a company must play a key role in nonmarket strategy, and I was at the forefront of these efforts at Samsung.

\section{Conclusion}

What is the role of the communications team in a company, and how does this role manifest? Various interests co-exist within a company, and as with any matter, there is always an is-

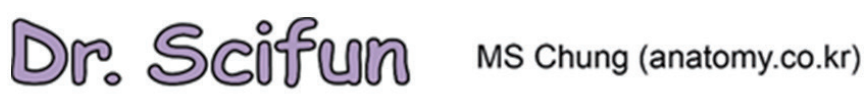

Communication of company, research lab

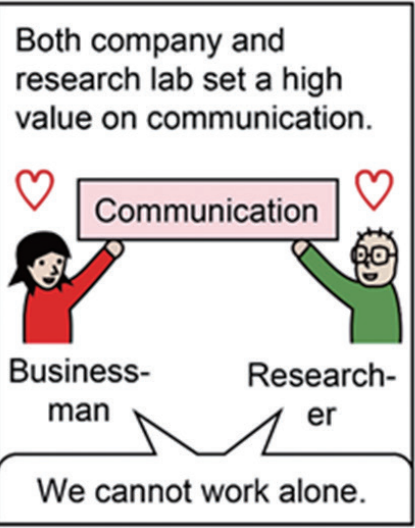

The two always care about the representative tools of commnication.

The two regard the counterparts' viewpoints for communication.
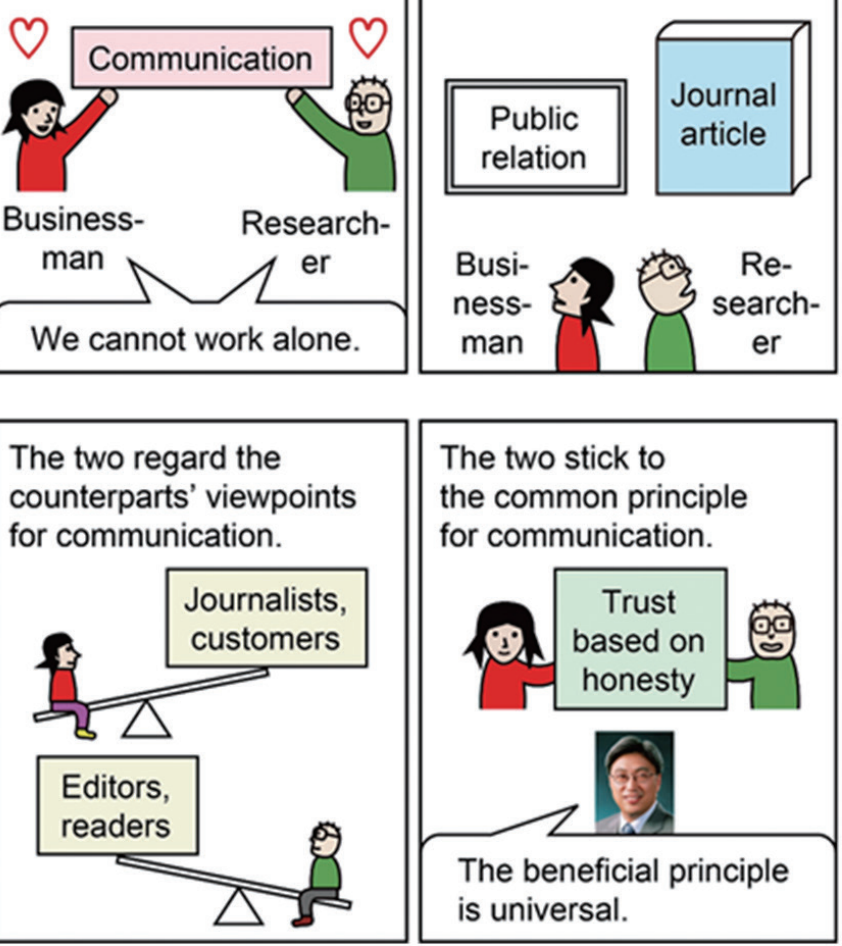

The two stick to the common principle for communication.

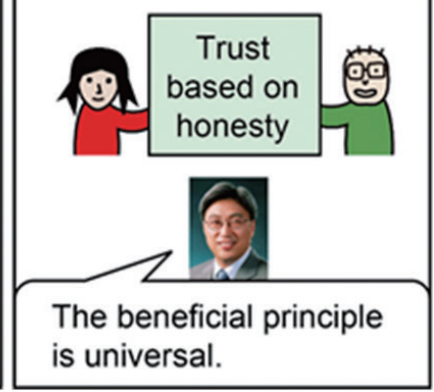

sue of responsibility. Whatever the concern, there are bound to be some departments that do not want transparent communication. Such situations require the communications team to take on a leadership role. The communications team should be able to determine from an outside perspective what is needed for the company in a given situation and to persuade the internal departments involved. We must look at the issue from the outside and drag it to the inside. From this external perspective, we can see what to do, how to do it, and how the work should be prioritized. This is called risk management or crisis management.

I would go as far as to suggest that the communications team is the opposition party within a company. Through its role as opposition, the communications team should be at the core of risk management. I have also stressed that there is no shortcut to improve communications with the public or market; furthermore, there is no answer but to build trust in a way that starts with trivial matters.

And of course, if a significant accident happens just as we 
are building trust, that trust may fall apart. Then, we have no choice but to build it up again.

\section{Conflict of Interest}

In Yong Rhee was the first President of Corporate Relations of Samsung Electronics Co., Ltd., from 2012 to 2017. He returned to this position on January 20, 2020. No other potential conflict of interest relevant to this article had been reported.

\section{References}

1. Watson B. The complete works of Chuang Tzu. New York: Columbia University Press; 1968.

2. Kongzi. The Xì Cí [繫辭], one of the chapters in the Book of Changes [周易].

3. Thucydides. The history of the Peloponnesian War: translated by Richard Crawley [Internet]. 2009 May 1 [cited 2019 Jan 3]. Available from: https://www.gutenberg.org/ files/7142/7142-h/7142-h.htm 